Dicle University Journal of Engineering (DUJE)

web: http://dergipark.gov.tr/dumf

Araştırma Makalesi / Research Article

\title{
Betonarme Kirişlerde Makro Fiber Sentetik Katkı Kullanımının Etkileri
}

\section{Effects of Using Macro Fiber Synthetic Additives in Reinforced Concrete Beams}

\author{
Selçuk KAÇIN ${ }^{1 *}$, Fatma SOYALAN², Orhan KAHRAMAN ${ }^{3}$ \\ ${ }^{1}$ İskenderun Teknik Üniversitesi,İnşaat Mühendisliği Böümü, İskenderun-Hatay, selcuk.kacin@ iste.edu.tr ORCID 0000-0001-5406-5756 \\ 2 İskenderun Teknik Üniversitesi,İnşaat Mühendisliği Böümü, İskenderun-Hatay, fatmasoyalan.mfbe17@iste.edu.tr, ORCID 0000-0001-7065-1229 \\ 3 İskenderun Teknik Üniversitesi,İnşaat Mühendisliği Böümü, İskenderun-Hatay, orhankahraman.mfbe17@iste.edu.tr, ORCID 0000-0001-5208-980X
}

\begin{tabular}{|c|c|}
\hline MAKALE BİLGİLERİ & ÖZET \\
\hline Makale geçmişi: & \multirow{6}{*}{ 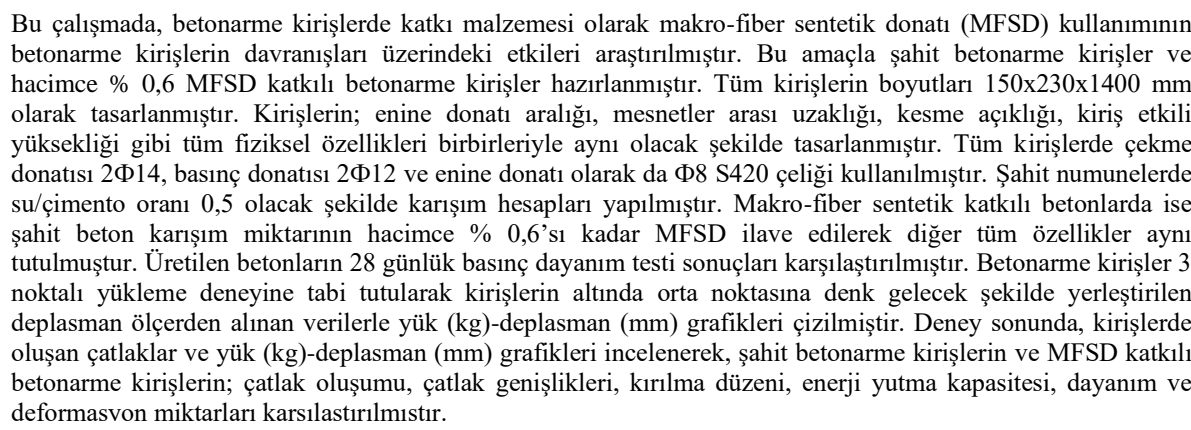 } \\
\hline Geliș: 20 Mart 2020 & \\
\hline Düzeltme: 25 Nisan 2020 & \\
\hline Kabul: 27 Nisan 2020 & \\
\hline Anahtar kelimeler: & \\
\hline $\begin{array}{l}\text { Süneklik, polipropilen lif, kiriş } \\
\text { yükleme deneyi, enerji yutma } \\
\text { kapasitesi, makro-fiber sentetik }\end{array}$ & \\
\hline
\end{tabular}

Doi: $10.24012 /$ dumf. 706338

\begin{tabular}{|c|c|}
\hline ARTICLE INFO & ABSTRACT \\
\hline $\begin{array}{l}\text { Article history: } \\
\text { Received: } 20 \text { May } 2020 \\
\text { Revised: } 25 \text { April } 2020 \\
\text { Accepted: } 27 \text { April } 2020\end{array}$ & $\begin{array}{l}\text { In this study, the effects of the use of macro-fiber synthetic reinforcement (MFSD) as an additive material in } \\
\text { reinforced concrete beams on the behavior of concrete beams were investigated. For this purpose, reinforced } \\
\text { concrete beams and } 0,6 \% \text { by volume MFSD reinforced concrete beams were prepared. The dimensions of all } \\
\text { beams are designed as } 150 \times 230 \times 1400 \mathrm{~mm} \text {. the beams; It is designed so that all physical properties such as } \\
\text { transverse reinforcement spacing, aperture between supports, cutting span, beam effective height are the same. }\end{array}$ \\
\hline $\begin{array}{l}\text { Keywords: } \\
\text { Ductility, polypropylene fiber, } \\
\text { beam loading test, energy } \\
\text { absorption capacity, macro-fiber } \\
\text { synthetic. }\end{array}$ & $\begin{array}{l}\text { Tension reinforcement } 2 \Phi 14 \text {, pressure reinforcement } 2 \Phi 12 \text { and } \Phi 8 \text { S420 steel were used as transverse } \\
\text { reinforcement in all beams. In the concrete mixtures used in the study, CEMI } 42,5 \text { cement, coarse }(4-11 \mathrm{~mm}) \\
\text { aggregate, fine }(0-4 \mathrm{~mm}) \text { aggregate and water were used. Mixing calculations were made with a water/cement } \\
\text { ratio of } 0.5 \text {. In macro-fiber synthetic reinforced concrete, } 0.6 \% \text { of the amount of concrete mixture is added with } \\
\text { the volume of MFSD and all other properties are kept the same. 28-day compressive strength test results of the } \\
\text { concretes produced were compared. Reinforced concrete beams are subjected to 3-point loading test and load (kg) } \\
\text {-displacement (mm) plots were drawn with the data obtained from the displacement meter placed under the beams } \\
\text { corresponding to its mid-point. At the end of the experiment, cracks formed in beams and load (kg)-displacement } \\
\text { (mm) graphs are examined and witnessed reinforced concrete beams and reinforced concrete beams with MFSD; } \\
\text { crack formation, crack widths, breaking order, energy absorption capacity, strength and deformation amounts were } \\
\text { compared. }\end{array}$ \\
\hline
\end{tabular}

* Sorumlu yazar / Correspondence

Selçuk KAÇIN $\bowtie$ selcuk.kacin@iste.edu.tr 


\section{Giriş}

Beton su, çimento ve agregadan oluşan kompozit bir malzemedir. Yol, konut, tünel, köprü, baraj ve su yapıları gibi birçok alanda özellikle taşıyıcı elemanların tasarımında çokça tercih edilen ve kullanım alanı giderek genişleyen önemli bir yapı malzemesidir fakat fazlaca tercih edilmesine rağmen her özelliğiyle mükemmel bir malzeme değildir. Yapıların maruz kaldığı deprem yükü, rüzgâr yükü, donma- çözülme gibi olumsuz etkilere karşı beton tek başına dayanım sağlamakta yetersiz kalmaktadır. Bunun en belirgin örneği çekmeye karşı mukavemetinin ihmal edilebilecek kadar az olması ve bu mukavemeti elde edebilmek için taze betona demir donatılar ilave edilmesidir. Betonun enerji yutma kapasitesi, süneklik, çekme dayanımı, yorulma dayanımı, aşınma dayanımı, donma-çözülmeye karșı dayanımı, çatlak oluşumu gibi özelliklerini iyileştirmek için geçmişten günümüze deneysel çalışmaların 1şı̆̆ında çeşitli katkı malzemelerinin betonun davranışına etkisi araştırılmıştır ve hala da araştırılmaktadır. Betonun kullanımının yaygınlaşması 1900'lü yıllarda hazır beton üretimini başlatırken, ilerleyen teknoloji sayesinde yukarıda saydığımız özelliklerin iyileştirilmesi adına beton karışımlarında kimyasal ve mineral katkı malzemeleri kullanılmaya başlanmıştır. $\mathrm{Bu}$ süreci beton karışımlarında lif ve daha birçok malzeme kullanımı takip ederek yüksek performanslı betonlar üretilmeye başlanmıştır. [1].

Yapılar, yapılmaya başlandığı andan kullanım ömrü nihayet bulana dek birçok yük ve olumsuz etkiye maruz kalmaktadır. Yukarıda bahsettiğimiz betonun enerji yutma kapasitesi, süneklik, çekme dayanımı, yorulma dayanımı, aşınma dayanımı, donma-çözülmeye karşı dayanımı, çatlak oluşumu gibi özellikleri iyileştirilmediği takdirde ne yazık ki yapılarda büyük çatlaklar, kalıcı deformasyonlar ve taşıyıcı sistemin tamamen çökmesi gibi sorunlar ortaya çıkmaktadır. Bir mühendis olarak amacımız yapının maruz kaldığı olumsuz etkilere karşı durabilitesini arttırmak, deformasyonlara karşı direnç sağlamak ve olası bir yıkım halinde can kaybını minimuma indirecek yapılar tasarlamaktır. $\mathrm{Bu}$ amaç doğrultusunda literatürde; polipropilen lif [2-4], karbon lif [5], cam lif [6], çelik lif [7-12] ve makrosentetik lif [13] gibi katkı malzemeleri ile yapılan çalışmalar bulunmaktadır. $\mathrm{Bu}$ katkı malzemeleri ile gevrek kırılmaları engellemek, yapılara sünek davranış kazandırmak, yapıların yük altında sönümlediği enerji miktarını arttırmak, deformasyonları minimuma indirmek, basınç ve çekme dayanımını arttırmak, betonun tüm özelliklerini daha da iyileștirmek hedeflenmektedir.

Cucchiara [14] yaptığı çalışmada; betonarme kirişlere yapılan çelik lif takviyesinin çatlak genişliğini azalttığını vurgulamıştır. Kirişlerde enine donatı ve çelik lif kullanılması durumunda; enine donatının kesitin şekil değiştirme özelliğini arttırdığını, enine donatı kullanılan kirișlerin harcına çelik lif katıldığında kiriș kesme dayanımın olumu etkilendiğini ve çelik lif katkı malzemesinin enine donatı gibi kesme kuvvetine karşı mukavemet sağlayabileceğini belirtmiştir.

Karabulut [15]; sentetik lif ile üretilen ultra yüksek dayanıma sahip betonun eğilme davranışı 14 farklı numune üzerinden test etmiștir. 100X150X1500 mm boyutlarındaki kiriş numunelerinde 2 farklı donatı oranı $(2 \varphi 10$ ve $2 \varphi 14), 2$ farklı lif tipi (bazalt ve poliamid), 3 farkl1 lif oran1 $(\% 0.5, \% 1.0$ ve $\% 1.5)$ kullanılmıştır. Düşük donatı oranında $(2 \varphi 10)$ bazalt lifinin miktarının artışıyla sünek davranışın da arttığı gözlenmiştir. Yüksek donatı oranında $(2 \varphi 14)$ bazalt lifi artışının sünek davranışa etkise gözlemlenememiştir. Poliamid lif kullanılması durumunda düşük donatılı betonda lif miktarının artışıyla yük taşıma kapasitesinin arttığı gözlemlenirken, yüksek donatılı $(2 \varphi 14)$ betonda ancak en yüksek lif oranı eklendiğinde yük taşıma kapasitesinde artış görülmüştür. İki katkı maddesi birbiriyle karşılaştırıldığında; her ikisinin de betonun rijitliğini arttırdığı, düşük donatı oranına $(2 \varphi 10)$ sahip betonlarda sünekliği arttırdığı, poliamid lifin düşük donatı oranına $(2 \varphi 10)$ sahip betonlarda bazalt lifine oranla taşıma gücü kapasitesinde daha fala artış sağladığı gibi birçok sonuca ulaşılmıștır. 
150X200X1900 mm boyutlarında kirişlerle yapılan çalışmada çelik lif katkısının çatlaklar ve taşıma gücü üzerindeki etkisi incelenmiştir. Tüm kiriş numunelerinin boyutları 150X200X1900 mm, boyuna donat oran $\rho \mathrm{l}=0.0067 \quad(4 \Phi 8), \quad$ enine donat 1 oran 1 $\rho w=0.00586$ ve son olarak enine donat 1 aralığ test bölgesi dışında $50 \mathrm{~mm}$, test bölgesinde 200 $\mathrm{mm}$ olacak şekilde tasarım yapılmıştır. Boyutları ve özellikleri verilen bu kiriş numunelerine $\% 0.3$ ve $\% 0.6$ olmak üzere iki farklı oranda çelik lif katkısı ilave edilmiştir. Böylelikle çelik lif katkısı hacminin çatlak ve taşıma gücüne etkisi gözlenmiştir. Elde edilen sonuçlara göre; $\% 0.3$ hacimde çelik lif katkısının taşıma kapasitesine kayda değer bir etkisi gözlemlenmezken \%0.6 hacimde eklenen çelik lifin taşıma kapasitesine kayda değer ve olumlu bir etki ettiği görülmüştür, çelik lif katkısı arttıkça çatlaklar artmakta, ortalama çatlak genişlikleri ise azalmaktadır. Bu durum ise çelik lif katkılı betonarme kirişlerin burulma altında enerji yutma kapasitelerinin arttığını göstermektedir [16].

$\mathrm{Bu}$ çalışmada kopolimer bir yapıya sahip olan makro fiber sentetik (MFSD) donatı kullanılarak betonun davranışları üzerindeki etkisi incelenmiştir. 2 farklı beton karışımı hazırlanarak aynı donatı düzenine ve kesit ölçülerine sahip betonarme kirişler hazırlanmıştır. Beton karışımının ilki hiçbir katk1 malzemesi kullanılmayarak yalnızca su, çimento ve agrega ile hazırlanmıştır. İkinci beton karışımında ilk beton karışımının özelliklerine sadık kalınarak ilkinden farklı olarak hacimce \%0,6 oranında MFSD katk1 malzemesi olarak kullanılmıştır. Yapılan 3 noktalı yükleme deneyi sonucunda elde edilen bulgular karşılaştırılarak MFSD kullanımının çatlak oluşumu, kırılma düzeni, enerji yutma kapasitesi ve dayanımı nasıl etkilediği yorumlanmıştır.

\section{Deneysel çalışma}

Numunelerin hazırlanmasında iki farklı seri beton harciyla 4 adet betonarme kiriş üretilmiştir. Kirişler Şahit1, Şahit2, 0.6MFSD1 ve 0.6 MFSD2 olarak adlandırılmıştır. Her iki seri beton karışımında su/çimento oranı, iri ve ince agrega oranları, çimento tipi ve dozajı sabit tutulmuştur. Beton karışımlarında CEM I42,5/R tipi Portland Çimentosu $(\mathrm{d}=3,1 \mathrm{~kg} / \mathrm{dm} 3$ ) kullanılmıştır.

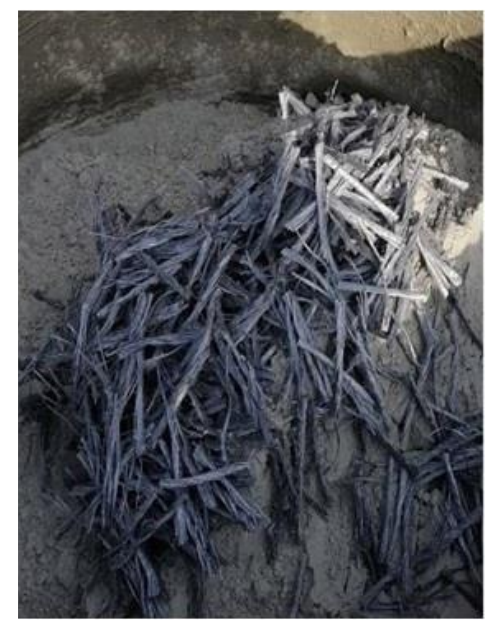

Şekil 1. Katkı malzemesi olarak kullanilan sentetik fiber malzeme

0.6MFSD1 ve 0.6MFSD2 kirişlerinin harcına hacimce $\% 0,6$ oranında makro fiber sentetik donatı (MFSD) ilave edilmiştir (Şekil 1). MFSD'ye ait teknik özellikler Tablo 1'de sunulmuştur.

Tablo 1. MFSD teknik özellikleri

\begin{tabular}{|c|c|}
\hline Karakteristik & Malzeme Özelliği \\
\hline Ham Madde & $\begin{array}{c}\% 100 \text { Saf Kopolimer } \\
\text { PP/PE }\end{array}$ \\
\hline Uzunluk & $54 \mathrm{~mm}$ \\
\hline Çekme Gerilmesi & $550-750 \mathrm{MPa}$ \\
\hline Elastisite Modülü & $5,75 \mathrm{GPa}$ \\
\hline Yüzey Dokusu & Deforme Edilmiş Yüzey \\
\hline Fiber Sayısı & 220.000 Parça/kg \\
\hline Yoğunluk & $0,91 \mathrm{~g} / \mathrm{cm} 3$ \\
\hline Erime Noktası & $162-168^{\circ} \mathrm{C}$ \\
\hline Yanma Noktas1 & $398^{\circ} \mathrm{C}$ \\
\hline Su Emilimi & Sifir \\
\hline Asit / Alkali & Mükemmel \\
\hline Direnci & \\
\hline Standart & ASTMC-1116 \\
\hline
\end{tabular}

Şahit1 ve Şahit2 olarak adlandırılan kirişlerde herhangi bir katkı malzemesi kullanılmamıştır. 
Beton karışım oranları Tablo 2'de detaylı olarak verilmiştir. Bu miktarlar bir kiriş için yani 0.048 $\mathrm{m}^{3}$ beton için kullanılan değerlerdir.

Tablo 2. Beton karışım oranları (bir kiriş için $0.048 \mathrm{~m}^{3}$ betonda kullanılan değerler)

\begin{tabular}{lcc}
\hline Bileşen & $\begin{array}{c}\text { Şahit } \\
\text { Numuneler }\end{array}$ & $\begin{array}{c}\text { MFSD Katk1lı } \\
\text { Numuneler }\end{array}$ \\
\hline Çimento & $28.22 \mathrm{~kg}$ & $28.22 \mathrm{~kg}$ \\
İnce Agrega (0-4 & $50.66 \mathrm{~kg}$ & $50.66 \mathrm{~kg}$ \\
mm) & & \\
İri Agrega (4-11 & $33.86 \mathrm{~kg}$ & $33.86 \mathrm{~kg}$ \\
$\mathrm{~mm})$ & & \\
Su/çimento & 0.5 & 0.5 \\
MFSD & - & $0.312 \mathrm{~kg}$ \\
\hline
\end{tabular}

Tüm kirişlerin boyutları 150x230x1400 mm, enine donatı aralığ $200 \mathrm{~mm}$, mesnetler arası uzaklık $1000 \mathrm{~mm}$, kesme açıklığ $500 \mathrm{~mm}$, kiriş etkili yüksekliği $200 \mathrm{~mm}$ olacak şekilde tasarlanmıştır. Tüm kirişlerde çekme donatısı 2Ф14, basınç donatısı $2 \Phi 12$ ve enine donatı olarak da Ф8 S420 çeliği kullanılmıştır. Kirişlerin boyutları ve donatı düzeni Şekil 2'de gösterilmiştir. Kirişlerin rahat taşınabilmesi için üst yüzeyine iki adet kanca yapılmıştır (Şekil 7).

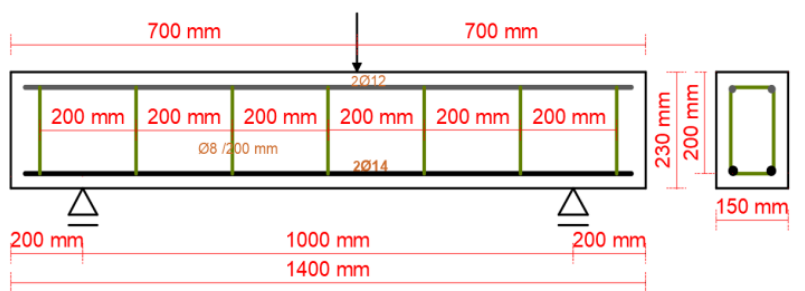

Şekil 2. Kirişlerin boyutları ve donatı düzeni

Beton karışımları beton mikseri ile laboratuvarımızda hazırlanmıştır. MFSD katkılı harçlar hazırlanırken homojen bir karışım elde edebilmek için çimento, agrega ve MFSD 1 dakika kuru halde mikserde karıştırılmış (Şekil 3) ardından su eklenerek tamamen homojen olana kadar 5 dakika karıştırılmıştır (Şekil 4).

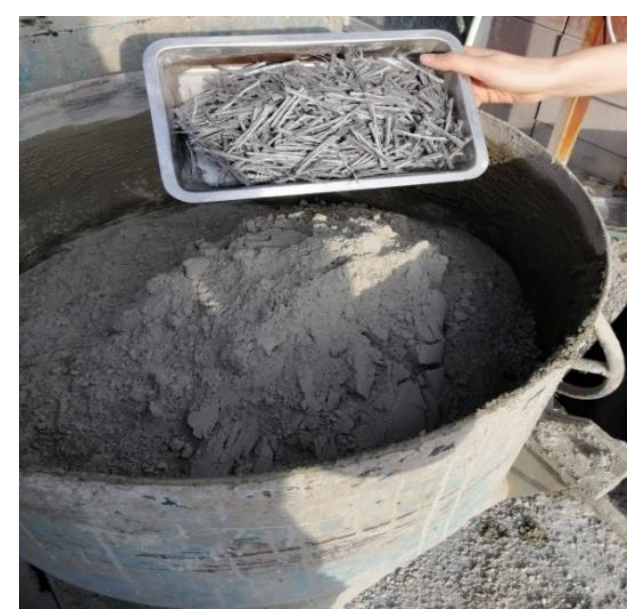

Şekil 3. Beton karışımına MFSD katılması

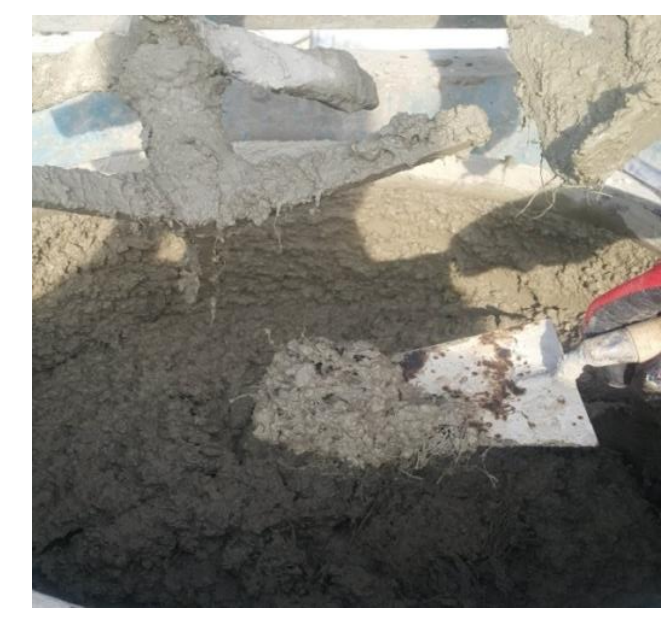

Şekil 4. MFSD katkılı beton karışımı

Beton harçlarından 150X150X150 mm küp numuneler alınarak 28 günlük basınç dayanımları test edilmiştir (Şekil 5).

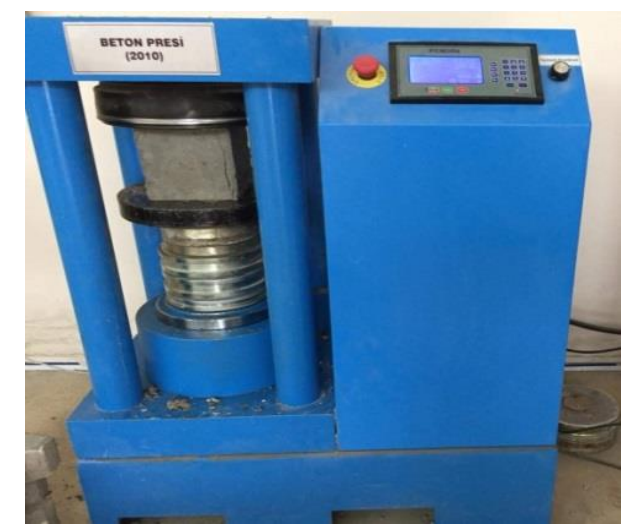

Şekil 5. Küp numunelerin basınç dayanım testi

Basınç dayanımı test sonuçları Tablo 3'de verilmiştir. 
Tablo 3. $150 X 150 X 150 \mathrm{~mm}$ küp numunelerin basınç dayanımı

\begin{tabular}{lc}
\hline Karışım No & $\begin{array}{c}\text { 28 Günlük Basınç } \\
\text { Dayanımı }(\mathrm{MPa})\end{array}$ \\
\hline Şahit & 36.584 \\
MFSD & 39.72 \\
\hline
\end{tabular}

Hazırlanan harçlar yağlanan ve $3 \mathrm{~cm}$ pas payı bırakılarak donatısı yerleștirilen kalıplara dökülüp kalıba homojen yerleşmesi sağlanmıştır, kalıplar işkencelerle sıkıştırılarak kalıpların esneme yapması engellenmiştir (Şekil $6)$.

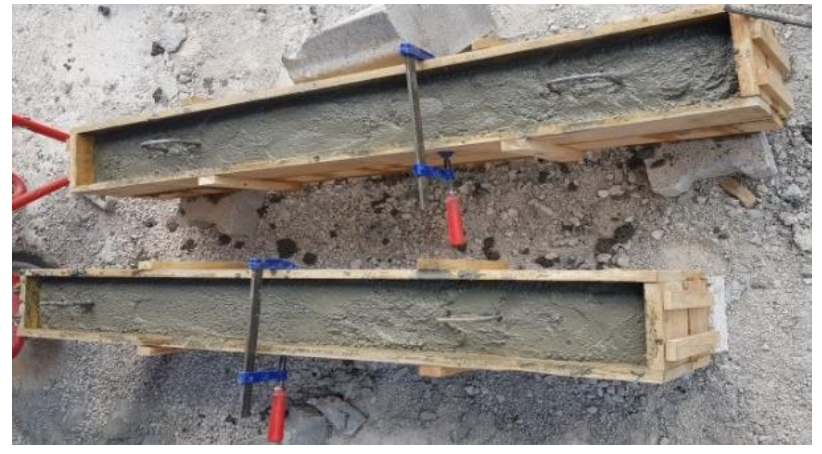

Şekil 6. Betonun kalıplara dökülmesi

7 günlük düzenli kür işlemi ardından kirişler kalıplardan çıkartılmıştır ve 28 gün boyunca kür işlemine devam edilmiştir (Şekil 7).

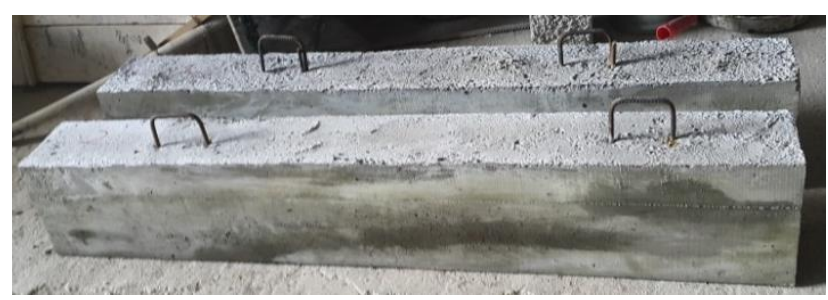

\section{Şekil 7. 7 günlük kür işlemi ardından kalıptan} çıkarılan kirişler

Kirişler 28 günlük dayanım kazandıktan sonra 3 noktalı yükleme deneyine tabi tutulmuştur. Yük hücresi; kirişin tam ortasından, mesnetlerin merkezine uzaklığı $500 \mathrm{~mm}$ olacak șekilde kirişin üzerine yerleștirilmiștir. Deplasman ölçer yine kirişin orta noktasına denk gelecek şekilde yük hücresinin düşeyine yerleştirilmiștir (Şekil 8).

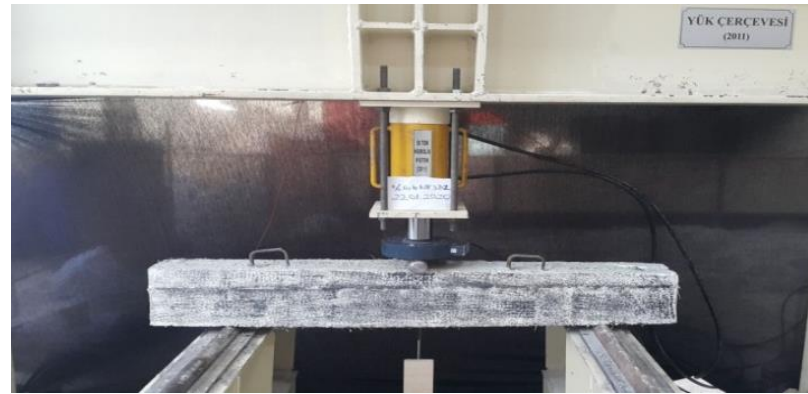

Şekil 8. Kirişlerin yük çerçevesine yerleştirilmesi

$50 \mathrm{KN}$ kapasiteli yük hücresi ile kiriş göçme noktasına gelene kadar yükleme yapılmıştır. Yükleme sirasında yük hücresinden ve deplasman ölçerden alınan veriler bilgisayara aktarılmış (Şekil 9) ve her bir kiriş için yükdeplasman grafikleri elde edilmiştir.

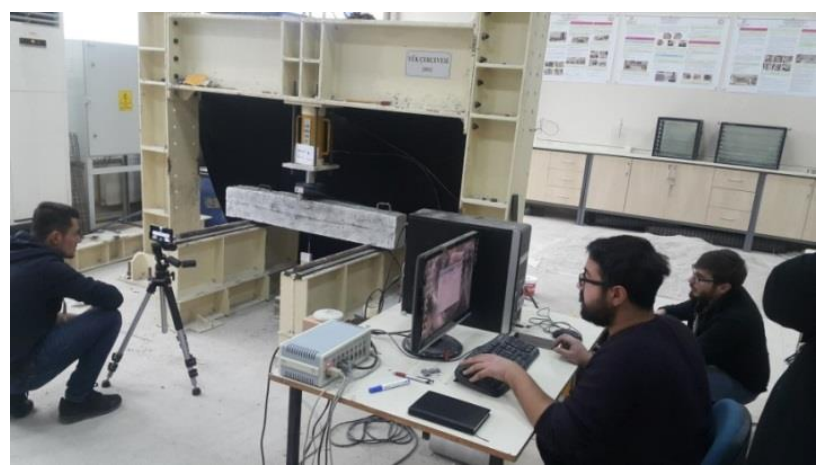

Şekil 9. 3 noktall yükleme deneyi ve verilerin toplanmast

\section{Deneysel bulgular}

Katk1sız ve hacimce \%0,6 MFSD katkılı betonlarla hazırlanan betonarme kirişler üzerinde yapılan deneysel çalışma bulguları şöyledir:

- 3 noktalı yükleme deneyi sonunda yük $(\mathrm{kg})$ deplasman $(\mathrm{mm})$ grafiği elde edilmiştir (Şekil 10). 


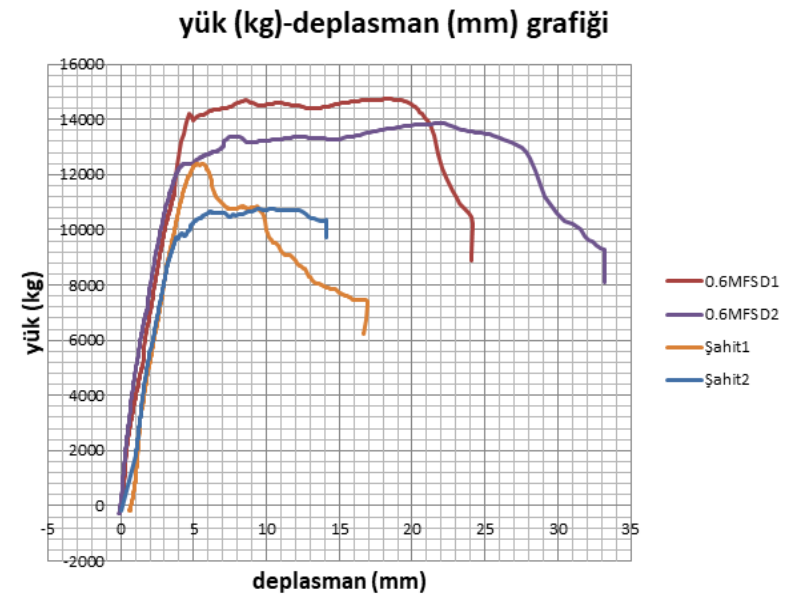

Şekil 10. Yük (kg)-deplasman (mm) grafiğ $i$

- Şahit1 kirişinin taşıyabildiği maksimum yük 12,381 ton ve bu yük altında oluşan kirişin orta noktasından ölçülen düşey deplasman 5,217 mm olarak okunmuştur.

- Şahit2 kirişinin taşıyabileceği maksimum yük 9,862 ton ve bu yük altında oluşan kirişin orta noktasından ölçülen düşey deplasman 4,185 mm olarak okunmuştur.

- $0.6 \mathrm{MFSD} 1$ kirişinin taşıyabileceği maksimum yük 14,735 ton ve bu yük altında oluşan kirişin orta noktasından ölçülen düşey deplasman $18,221 \mathrm{~mm}$ olarak okunmuştur.

- 0.6MFSD2 kirişinin taşıyabileceği maksimum yük 13,868 ton ve bu yük altında oluşan kirişin orta noktasından ölçülen düşey deplasman 21,975 $\mathrm{mm}$ olarak okunmuştur.

\section{Sonuçlar}

Beton harçlarından alınan 150X150X150 mm küp numunelerin basınç dayanımları karşılaştırıldığında (Şekil 11) MFSD katkılı betonun basınç dayanımının \%8,57 arttığ görülmüştür.

\section{8 günlük basınç dayanımları (\%)}

॥ Şahit1 ve Şahit2 $\quad 0.6 \mathrm{MFSD1}$ ve 0.6MFSD2

108,57

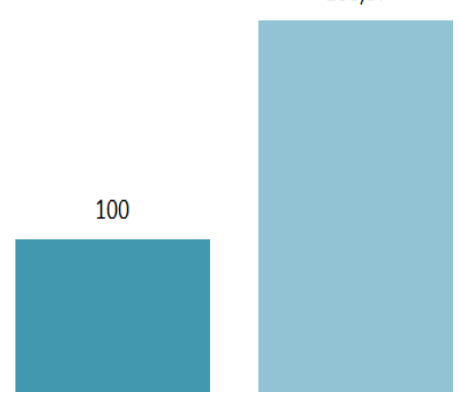

Şekil 11. Küp numunelerin basınç dayanımlarının karşılaştırılması

150X150X150 mm küp numunelerin basıç dayanımı testine tabi tutulduktan sonra deformasyonları karşılaştırılmıştır. Şahit1 ve Şahit2 betonlarından alınan küp numunelerinin köşelerinde kırılmalar, dağılmalar, dökülmeler ve gözle görülebilir deformasyonlar meydana geldiği gözlemlenmiştir (Şekil 12).

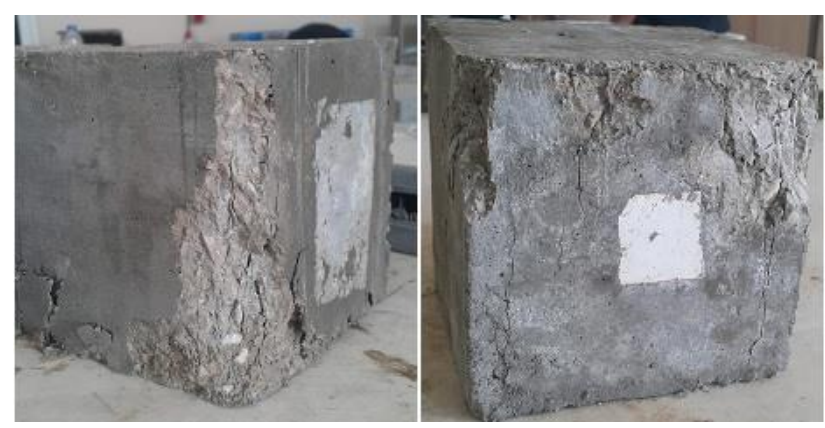

\section{Sekil 12. Sahit1 ve Sahit2 küp numunelerinin basınç dayanımı test edildikten sonraki durumlart}

0.6MFSD1 ve $0.6 \mathrm{MFSD} 2$ betonlarından alınan küp numunelerde kılcal çatlaklar olduğu ve şahit beton numunelerine oranla yok denecek kadar az deformasyon olduğu gözlemlenmiştir (Şekil 13). 


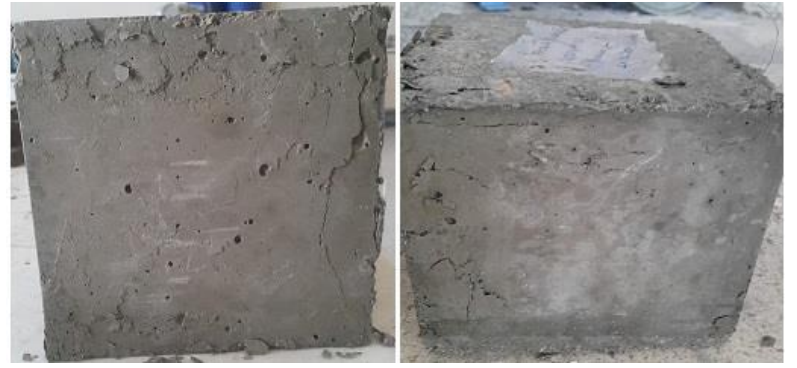

Şekil 13 .0.6MFSD1 ve 0.6MFSD2 küp numunelerinin basınç dayanımı test edildikten sonraki durumlart

3 noktalı yükleme deneyi sonrasında şahit kirişlerin betonu kolayca parçalanabilirken MFSD katkılı kirișlerin içerisindeki liflerin bu parçalanmaya ve kopmalara karşı direnç sağladiğ1 görülmüştür. 3 noktalı yükleme deneyi sonrasında kirişlerin yük taşıma kapasiteleri karşılaştırıldığında MFSD katkısının yük taşıma kapasitesini yaklaşık $\% 28,59$ oranında arttırdığg görülmüştür (Şekil $14)$.

\section{Kirişlerin yük taşıma kapasiteleri (\%)}

चŞAHIT (KATKISIZ) — \%0,6 MFSD

128,5934129

100

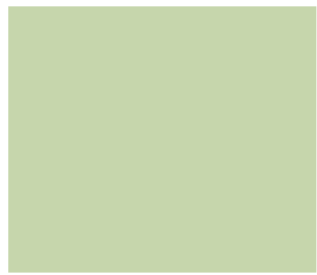

Şekil 14. MFSD katkısının kirişlerin yük taşıma kapasitesine etkisi

Şekil 15.'de sırasıyla Şahit1, Şahit2, 0.6MFSD1 ve $0.6 \mathrm{MFSD} 2$ kirişlerinin 3 noktalı yükleme deneyi sonrası durumları görülmektedir.

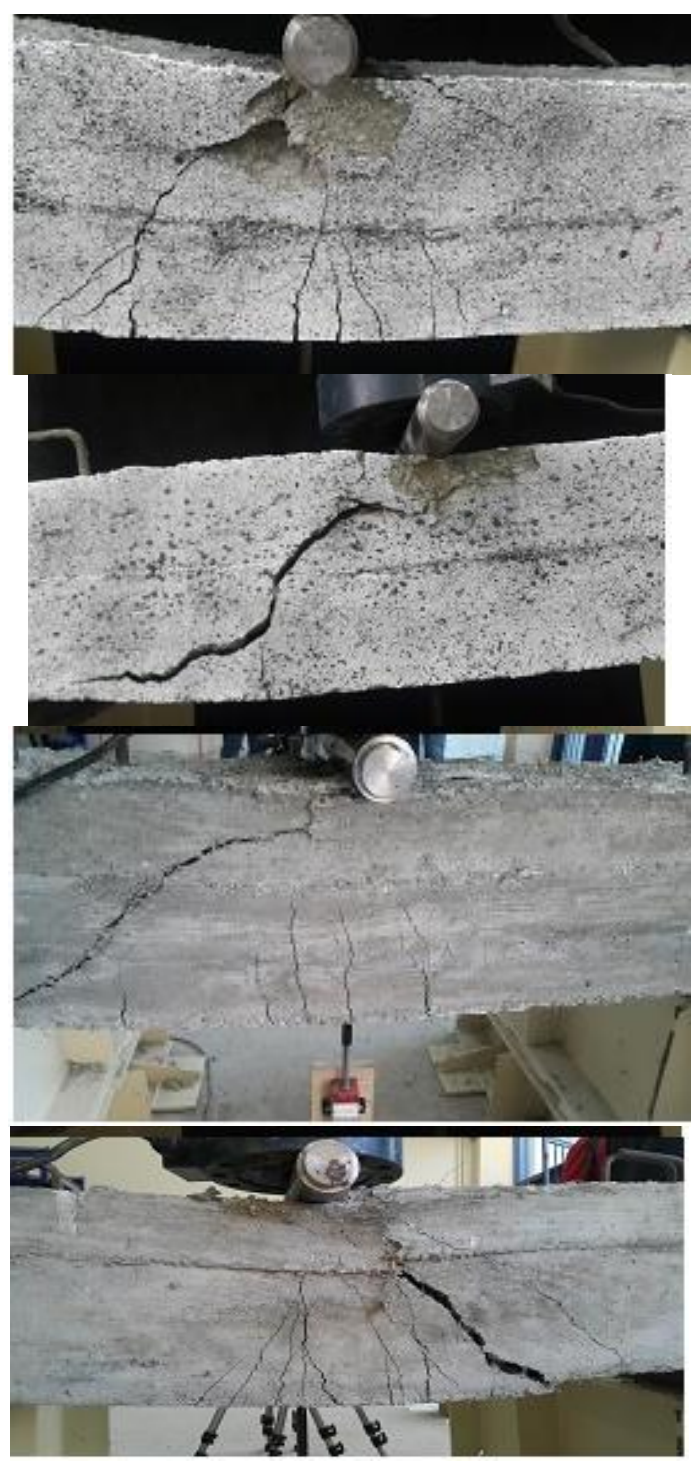

Şekil 15. Sirastyla; Şahit1, Şahit2, 0.6MFSD1 ve 0.6MFSD2 kirişlerinin 3 noktall yükleme deneyi sonrass durumlart

Elde edilen yük (kg)-deplasman (mm) eğrilerinin (Şekil 9) altında kalan alan incelendiğinde MFSD katkılı kirişlerin, şahit yani katkısız kirișlere oranla daha büyük bir enerji yutma kapasitesine sahip olduğu görülmüştür.

Elde edilen yük (kg)-deplasman (mm) eğrilerine (Şekil 10) ve çatlak oluşumlarına (Şekil 12) bakıldığında Şahit1 ve Şahit2 kirişlerinin gevrek kırıldığı, 0.6MFSD1 ve 0.6MFSD2 kirişlerinin ise daha sünek davranış gösterdiği gözlemlenmiştir. 
$\mathrm{Bu}$ deneysel çalışmada elde edilen görseller ve yük (kg)-deplasman (mm) eğrileri 1şı̆̆ında hacimce \%0.6 MFSD katkısının süneklik ve enerji yutma kapasitesini arttırdığ1, deformasyonları minimuma indirebildiği, yük taşıma kapasitesinde ve küp numunelerin basınç dayanımında artış sağladığı sonuçlarına varılmıştır.

\section{Kaynaklar}

[1] Karakule, F., Akakın, T., \& Uçar, S. (2004). "Türkiye' de ve Dünyada Hazır Beton Sektörü"

[2] Aryan, A. (2014). "Polipropilen lif takviyeli betonarme kirişlerin deneysel ve analitik olarak araştırılması", Y. Lisans Tezi, Selçuk Üniversitesi, Fen Bilimleri Enstitüsü

[3] Akkaş, A., Alpaslan, L., Arabaci, S., \& Başyiğit, C. (2010). "Polipropilen Lif Katkili Yari Hafif Betonlarin Basinç Dayanimi Özellikleri”, Uluslararası Teknolojik Bilimler Dergisi, 2(1), 9-14.

[4] Yaprak, H., \& Karac1, A. (2009). "Polipropilen lifli betonların yüksek sıcaklık sonrası basınç dayanımlarının yapay sinir ağları ile tahmini”, Uluslararası Mühendislik Araştırma ve Geliştirme Dergisi, 1(2), 23-28.

[5] Topçu, İ. B., Demirel, O. E., \& Uygunoğlu, T. (2017). "Polipropilen lif katkılı harçların fiziksel ve mekanik özelikleri", Politeknik Dergisi, 20(1), 91-96.

[6] Çetinkaya, N., Kaplan, H., \& Şenel, Ş. M. (2011). "Betonarme Kirişlerin Lifli Polimer (FRP) Malzemeler Kullanılarak Onarım ve Güçlendirilmesi” Pamukkale Üniversitesi Mühendislik Bilimleri Dergisi, 10(3), 291-298.

[7] Birincioğlu M. İ., (2016). "Çelik Lifli Betonarme Kirişlerin Kesme Mukavemeti”, Y. Lisans Tezi, Yıldız Teknik Üniversitesi, Fen Bilimleri Enstitüsü

[8] Kozak, M. (2003). "Çelik lifli betonlar ve kullanım alanlarının araştırılması", Süleyman Demirel Üniversitesi, Teknik bilimler Dergisi, 3(5), 26-35.

[9] Can Ö., Durmuş G., Subaşı S., Yıılız K., Arslan M., (2009). "Lif Katkılı Betonların
Aşınma Direnci Üzerindeki Etkileri”, 5. Uluslararasi İleri Teknolojiler Sempozyumu (IATS'09), 13-15 Mayıs, Karabük, Türkiye

[10] Koç, V., \& Birinci, F. (2012). "Lifli Betonda Boyut Etkisi Tokluk ve Kırılma Enerjisi", Uluslararası Teknolojik Bilimler Dergisi, 4(3), 24-40

[11] Çivici, F. (2006). "Çelik Lif Donatılı Betonun Eğilme Tokluğu", Pamukkale Üniversitesi Mühendislik Bilimleri Dergisi, 12(2), 183-188.

[12] Altun, F., Y1lmaz, C., Durmuş, A., \& Kamuran, A. R. I. (2006). "Çelik Lif Katkılı ve Katkısız Betonarme Kirișlerin Basit Eğilme ve Patlama Yüklemesi ile Davranışlarının İncelenmesi" Erciyes Üniversitesi Fen Bilimleri Enstitüsü Fen Bilimleri Dergisi, 22(1), 112-120.

[13] Sarı M., (2013). "Farklı Tipteki Liflerin Betonun Mekanik Davranışına Etkisi”, Y. Lisans Tezi, İTÜ, Fen Bilimleri Enstitüsü

[14] Cucchiara, C., La Mendola, L., \& Papia, M. (2004). "Effectiveness of stirrups and steel fibres as shear reinforcement", Cement and concrete composites, 26(7), 777-786.

[15] Karabulut, M. Y. (2017). "Sentetik lifin ultra yüksek dayanımlı betonarme kirişlerin eğilme davranışına etkisinin incelenmesi”, Y. Lisans Tezi, Balıkesir Üniversitesi, Fen Bilimleri Enstitüsü

[16] Okay, F., \& Engin, S. (2009). "Çelik Lif Katkılı Betonarme Kirişlerde Basit Burulma Etkisinde Oluşan Çatlakların ve Kesit Taşıma Gücünde Oluşan Değişimlerin İncelenmesi" Uluslararası Sakarya Deprem Sempozyumunu, 1-3 Ekim, Sakarya 